\title{
Pengaruh Kecanggihan Teknologi Informasi, Partisipasi Pengguna, dan Kemampuan Pengguna Terhadap Kinerja Sistem Informasi Akuntansi pada PT. PLN (Persero) Area Jember
}

\author{
Ella Wahyu Ningtiyas ${ }^{1}$, Diyah Probowulan², Nina Martiana ${ }^{3}$ \\ ${ }^{123}$ Fakultas Ekonomi Program Studi Akuntansi Universitas Muhammadiyah Jember
}

\author{
A R T I C L E I N F O \\ Article history: \\ Received 19 August 2019 \\ Received in revised form \\ 16 September 2019 \\ Accepted 15 October 2019 \\ Available online 30 \\ November 2019

\begin{tabular}{l}
\hline Kata Kunci: \\
Kecanggihan Teknologi \\
Informasi, Partisipasi \\
Pengguna, Kemampuan \\
Pengguna, Kinerja Sistem \\
Informasi Akuntansi. \\
\\
Keywords: \\
Sophisticated Information \\
Technology, User \\
Participation, User \\
Capability, Accounting \\
Information System \\
Performance.
\end{tabular} \\ Kata Kunci: \\ Kecanggihan Teknologi \\ Pengguna, Kemampuan \\ Pengguna, Kinerja Sistem \\ Performance.
}

\begin{abstract}
A B S T R A K
Penelitian ini bertujuan untuk mengetahui pengaruh kecanggihan teknologi informasi, partisipasi pengguna, dan kemampuan pengguna terhadap kinerja sistem informasi akuntansi pada PT. PLN (Persero) area Jember. Penelitian ini menggunakan pendekatan kuantitatif dengan jenis penelitian explanatory (penjelasan). Populasi dalam penelitian ini adalah 35 karyawan bagian keuangan, sumberdaya manusia, administrasi, pemasaran, dan perencanaan di PT. PLN (Persero) Area Jember. Teknik pengambilan sampel menggunakan teknik purposive sampling. Teknik analisis yang digunakan dalam penelitian ini adalah regresi linear berganda dan pengujian data yang dilakukan menggunakan program SPSS (Statistical Product and Service Solution). Hasil penelitian ini menunjukkan bahwa variabel kecanggihan teknologi informasi dan kemampuan pengguna berpengaruh positif terhadap kinerja sistem informasi, sedangkan partisipasi pengguna berpengaruh negatif terhadap kinerja sistem informasi akuntansi.
\end{abstract}

\section{A B S T R A C T}

This study aims to determine the effect of the sophistication of information technology, user participation, and the ability of users on the performance of accounting information systems at PT. PLN (Persero) in Jember area.This study uses a quantitative approach with a type of explanatory research (explanation). The population in this study were 35 employees in the finance, human resources, administration, marketing and planning departments at PT. PLN (Persero) Jember Area. The sampling technique uses purposive sampling technique. The analysis technique used in this study is multiple linear regression and data testing carried out using the SPSS program (Statistical Product and Service Solution).The results of this study indicate that the sophistication of information technology and user capabilities has a positive effect on information system performance, while user participation has a negative effect on the performance of accounting information systems.

\footnotetext{
* Corresponding author.

E-mail addresses: EllaWahyuNingtiyas01@gmail.com (Ella Wahyu Ningtiyas)
} 


\section{Pendahuluan}

Perkembangan teknologi informasi telah banyak membantu meningkatkan kinerja Sistem Informasi Akuntansi (SIA). Peningkatan teknologi komputer sebagai salah satu bentuk teknologi informasi telah mengubah pemrosesan data akuntansi dari secara manual menjadi secara otomatis. Dengan menggunakan komputer, penyajian informasi akan menjadi lebih tepat, cepat, dan akurat. Pengaruh komputer sangat besar bagi perusahaan dalam hal sistem informasi dan pengambilan keputusan manajemen.

Sistem informasi akuntansi dirancang untuk mengatur arus dan pengelolaan data akuntansi dalam perusahaan sehingga data keuangan yang ada didalam perusahaan dapat bermanfaat dan dijadikan dasar pengambilan keputusan, baik bagi pihak manajemen maupun pihak lain diluar perusahaan. Peranan sistem informasi akuntansi dalam suatu perusahaan sangat penting dan diperlukan oleh pihak manajemen. Disamping itu sistem informasi akuntansi juga berperan sebagai sumber informasi yang digunakan sebagai dasar pertimbangan dalam pengambilan keputusan bagi manajemen.

Teknologi informasi yaitu komputer yang sangat membantu kinerja dalam organisasi. Kecanggihan teknologi mampu menghasilkan data yang akurat dan tepat waktu. Partisipasi pengguna digunakan untuk menunjukkan intervensi personal yang nyata dari pemakai dalam pengembangan sistem informasi mulai dari tahap perencanaan, pengembangan, sampai pada tahap implementasi sistem informasi. Kemampuan pengguna sistem informasi sangat bermanfaat dan beperan penting dalam pengembangan sistem informasi untuk dapat menghasilkan informasi guna menciptakan laporan perencanaan yang akurat dan dapat dipercaya. Suatu sistem informasi akan lebih bermanfaat dalam membantu aktivitas, apabila personal yang menggunakan sistem informasi memiliki kemampuan untuk mengoperasikan sistem informasi tersebut.

PT. PLN (Persero) merupakan Badan Usaha Milik Negara yang bergerak dalam bidang penyediaan dan pendistribusian energi listrik bagi masyarakat. PT. PLN (Persero) merupakan perusahaan publik yang bergerak dibidang jasa sehingga memiliki tanggung jawab besar untuk mampu memberikan pelayanan yang terbaik kepada masyarakat. Dalam melaksanakan kegiatan operasi perusahaan diperlukan adanya manajemen perusahaan PT. PLN (Persero) Area Jember yang baik dengan ditunjang oleh personil yang berkualitas agar dapat berkarya secara efisien. Hal penting yang harus diperhatikan oleh perusahaan adalah kinerja sistem informasi akuntansi. Kinerja sistem informasi akuntansi pada PT.PLN (Persero) Area Jember merupakan faktor dominan dalam pencapaian suatu tujuan perusahaan. Agar kinerja sistem informasi akuntansi dapat semakin berkembang, maka diperlukan kecanggihan teknologi. Selain kecanggihan teknologi informasi, ada juga partisipasi pengguna dan kemampuan pengguna.

Kinerja sistem informasi akuntansi dapat dikatakan baik jika informasi yang diterima memenuhi harapan pengguna. Kinerja sistem informasi akuntansi dipengaruhi oleh faktor-faktor yang meliputi kecanggihan teknologi informasi, partisipasi pengguna, dan kemampuan pengguna. Pada saat ini pada PT. PLN (Persero) Area Jember terdapat beberapa permasalahan, yaitu sering kali terjadi kesalahan staf dalam menyalin dan mengisi data yang berakibat pada keakurasian suatu laporan dan apabila terjadi gangguan teknis akan berakibat pada keakuratan atau keterlambatan atas laporan keuangan tersebut.

Menurut Azhar Susanto (2013) Sistem adalah kumpulan/group dari subsistem/ komponen apapun baik fisik maupun non fisik yang saling berhubungan satu sama lain dan bekerja sama secara harmonis untuk mencapai suatu tujuan tertentu.

Menurut Marshall B. Romney dan Paul Jhon Steinbart (2016) Informasi (Information) adalah data yang telah dikelola dan di proses untuk memberikan arti dan memperbaiki proses pengambilan keputusan. Sebagaimana perannya, pengguna membuat keputusan yang lebih baik sebagai kuantitas dan kualitas dari peningkatan informasi.

Menurut Marshall B. Romney dan Paul John Steinbart (2016) Akuntansi adalah proses identifikasi, pengumpulan, dan penyimpanan data serta proses pengembangan, pengukuran, dan komunikasi informasi.

Menurut Sutabri (2012 : 46), Sistem Informasi Akuntansi adalah suatu sistem didalam organisasi yang mempertemukan kebutuhan pengolahan transaksi harian yang mendukung fungsi operasi organisasi yang bersifat manajerial dengan kegiatan strategi dari suatu organisasi untuk dapat menyediakan kepada pihak luar tertentu dengan laporan-laporan yang diperlukan.

Menurut Mahsum (2006) kinerja sistem informasi akuntansi adalah gambaran mengenai tingkat pencapaian suatu kegiatan/ program/ kebijakan dalam mewujudkan sasaran, tujuan, misi, dan visi organisasi yang tertuang dalam strategi planning sistem informasi akuntansi suatu organisasi.

Menurut Hussin et al : (2012) mengidentifikasi bahwa kecanggihan teknologi mencerminkan keanekaragaman jumlah teknologi yang digunakan sedangkan kecanggihan informasi ditandai oleh sifat portofolio penerapannya. 
Menurut Rusmiati (2012) partisipasi pengguna adalah partisipasi mental dan emosional orangorang dalam situasi kelompok mendorong mereka untuk memberikan kontribusi kepada tujuan kelompok. Menurut Zain dan Badudu (2010 : 10) mengemukakan bahwa kemampuan pengguna adalah kesanggupan, kecakapan, kekuatan pengguna berusaha dengan diri sendiri.

\section{Metode}

Penelitian ini dilakukan pada PT. PLN (Persero) area Jember. Pendekatan yang digunakan dalam penelitian ini yaitu pendekatan kuantitatif dengan jenis penelitian explanatory (penjelasan). Variabel yang digunakan dalam penelitian ini yaitu kecanggihan teknologi informasi, partisipasi pengguna, kemampuan pengguna, dan kinerja sistem informasi akuntansi. Jenis data yang digunakan dalam penelitian ini yaitu kuantitatif berupa data skor jawaban kuesioner yang sudah terkumpul.

Sumber data yang digunakan dalam penelitian ini yaitu data primer berupa kuesioner dan data sekunder berupa bukti-bukti yang sudah didapatkan dari perusahaan. Populasi dalam ini adalah 35 karyawan bagian keuangan, sumber daya manusia, administrasi, pemasaran dan perencanaan di PT.PLN (Persero) area Jember. Teknik pengambilan sampel menggunakan teknik purposive sampling. Sampel yang diambil dalam penelitian ini 32 karyawan (91\% dari populasi). Teknik analisis data menggunakan pendekatan kuantitatif.

Model analisis kuantitatif yang digunakan disesuaikan dengan tujuan dan persoalan yang ingin dijawab serta hipotesis yang diajukan meliputi analisis statistik deskriptif, uji kualitas data (validitas dan reliabilitas), uji asumsi klasik (normalitas, analisis regresi linear berganda, multikolonieritas,dan heteroskedastisitas), dan uji hipotesis (parsial dan koefisien determinasi).

\section{Hasil dan pembahasan}

Uji Validitas

Pengujian validitas dilakukan dengan menggunakan produk moment, dimana uji validitas ditentukan dengan mengkorelasi skor masing-masing item pertanyaan terhadap skor total masing-masing item, jika nilai $r$ hitung yang diperoleh lebih besar $>$ dari 0,05\% maka instrument tersebut memenuhi kriteria validitas, sebaliknya jika nilai $r$ hitung yang dihasilkan lebih kecil $<$ dari 0,05 maka instrument tersebut tidak memenuhi kriteria validitas.

Uji Reliabilitas

Suatu variabel dikatakan reliable jika memberikan nilai Cronvach >0,60 (Ghozali,2006).

Tabel 1. Hasil Uji Reliabilitas

\begin{tabular}{llll}
\hline Variabel Penelitian & Alpha & Batas Kritis & Kesimpulan \\
\hline Kecanggihan Teknologi Informasi & 0,291 & 0,60 & Reliabel \\
Partisipasi Pengguna & 0,995 & 0,60 & Reliabel \\
Kemampuan Pengguna & 1,000 & 0,60 & Reliabel \\
Kinerja Sistem Informasi Akuntansi & 0,734 & 0,60 & Reliabel \\
\hline
\end{tabular}

Dari tabel diatas, terlihat bahwa nilai Cronbach Alpha dari tiap-tiap konstruk lebih besar dari 0,60 yang berarti bahwa kuesioner yang merupakan indikator-indikator dari variabel atau konstruk tersebut reliabel.

Uji Asumsi Klasik

Uji Normalitas

Uji normalitas bertujuan untuk menguji apakah dalam model regresi, variabel atau residual memiliki distribusi normal.

Tabel 2. Hasil Uji Normalitas

\begin{tabular}{lll}
\hline Variabel Penelitian & Alpha & Kesimpulan \\
\hline Kecanggihan Teknologi Informasi & 0,727 & Berdistribusi Normal \\
Partisipasi Pengguna & 0,978 & Berdistribusi Normal \\
Kemampuan Pengguna & 0,512 & Berdistribusi Normal \\
\hline
\end{tabular}


Dari tabel diatas dapat dilihat bahwa nilai signifikan yang dihasilkan oleh masing-masing variabel lebih besar dari 0,05. Sehingga dapat disimpulkan bahwa $\mathrm{H}_{0}$ ditolak. Hal ini berarti data yang ada dalam penelitian layak digunakan karena terbukti berdistribusi normal.

Analisis Regresi Linear Berganda

Analisis regresi digunakan untuk mengetahui pengaruh beberapa variabel independen terhadap variabel dependen.

Tabel 3. Hasil Analisis Regresi Linear Berganda

\begin{tabular}{lllll}
\hline Variabel & Koefisien & $\mathrm{t}$ & $\mathrm{Sig}$ & Kesimpulan \\
\hline Constant & $-0,510$ & $-0,071$ & 0,994 & - \\
Kecanggihan Teknologi Informasi & 0,748 & 2,217 & 0,035 & Signifikan \\
Partisipasi Pengguna & 0,234 & 1,333 & 0,193 & Signifikan \\
Kemampuan Pengguna & 0,500 & 3,183 & 0,004 & Signifikan \\
\hline
\end{tabular}

Sumber : Lampiran 6

Hasil persamaan regresi linear berganda menghasilkan model sebagai berikut :

$$
Y=-0,510+0,748 X 1+0,234 X 2+500 X 3+e
$$

Berdasarkan nilai koefisien regresi variabel kecanggihan teknologi informasi bernilai positif sebesar 0,748 menunjukkan bahwa mempunyai hubungan yang berbanding lurus dengan variabel dependen. Artinya jika kecanggihan teknologi informasi baik maka kinerja sistem informasi akuntansi akan meningkat dengan asumsi variabel lain bernilai tetap, nilai koefisien regresi variabel partisipasi pengguna bernilai positif sebesar 0,234 menunjukkan bahwa mempunyai hubungan yang berbanding lurus dengan variabel dependen. Artinya jika partisipasi pengguna meningkat maka kinerja sistem informasi akuntansi akan meningkat dengan asumsi variabel bernilai tetap, dan nilai koefisien regresi variabel kemampuan pengguna bernilai positif sebesar 0,500 menunjukkan bahwa mempunyai hubungan yang berbanding lurus dengan variabel dependen. Artinya semakin tinggi kemampuan pengguna maka kinerja sistem informai akuntansi akan semakin meningkat dengan asumsi variabel bernilai tetap.

Uji Multikolonieritas

Uji Multikolinearitas bertujuan untuk menguji apakah model regresi ditemukan adanya korelasi antar variabel bebas.

Tabel 4. Uji Multikolonieritas

\begin{tabular}{llll}
\hline \multirow{2}{*}{ Variabel Penelitian } & \multicolumn{2}{l}{ Collinearity Statistics } & \multirow{2}{*}{ Kesimpulan } \\
\cline { 2 - 3 } & Alpha & VIF & \\
\hline Kecanggihan Teknologi Informasi & 0,883 & 1,132 & Tidak ada multikolonieritas \\
Partisipasi Pengguna & 0,994 & 1,006 & Tidak ada multikolonieritas \\
Kemampuan Pengguna & 0,887 & 1,128 & Tidak ada multikolonieritas \\
\hline
\end{tabular}

Sumber : Lampiran 6

Dari tabel diatas dapat dilihat bahwa hasil output SPSS untuk VIF dan Tolerance mengidentifikasi tidak terdapat multikolineritas yang serius. Hal ini dikarenakan nilai VIF tidak ada yang melebihi 10 dan nilai tolerance tidak ada yang kurang dari 0,10.

Uji Heteroskedastisitas

Pengujian ini dilakukan untuk mengetahui ada atau tidaknya gejala heteroskedatisitas dalam model penelitian yang digunakan.

Tabel 5. Hasil Uji Heteroskedatisitas

\begin{tabular}{lll}
\hline Variabel Bebas & Nilai t & Sig. \\
\hline Kecanggihan Teknologi Informasi & 2,217 & 0,035 \\
Partisipasi Pengguna & 1,333 & 0,193 \\
Kemampuan Pengguna & 3,183 & 0,004 \\
\hline
\end{tabular}


Variabel Terikat $=$ Residual

Sumber : Lampiran 6

Dari Tabel 5 diatas dapat dilihat bahwa nilai signifikansi kecanggihan teknologi informasi sebesar $2,217>0,05$, partisipasi pengguna sebesar $1,333>0,05$, dan kemampuan pengguna 3,183 $>0,05$, jadi dapat disimpulkan bahwa semua variabel tidak terjadi heteroskedatisitas.

Uji Hipotesis

Uji Parsial (Uji T)

Uji satatistik $\mathrm{t}$ digunakan untuk menunjukkan seberapa jauh pengaruh pengaruh variabel independen secara individual dalam menerangkan variabel dependen.

Tabel 6. Uji Parsial (Uji T)

\begin{tabular}{lllll}
\hline Variabel & Koefisien & $\mathrm{t}$ & $\mathrm{Sig}$ & Kesimpulan \\
\hline Constant & $-0,510$ & $-0,071$ & 0,994 & - \\
Kecanggihan Teknologi Informasi & 0,748 & 2,217 & 0,035 & Berpengaruh Signifikan \\
Partisipasi Pengguna & 0,234 & 1,333 & 0,193 & Tidak Berpengaruh Signifikan \\
Kemampuan Pengguna & 0,500 & 3,183 & 0,004 & Berpengaruh Signifikan \\
\hline
\end{tabular}

Sumber : Lampiran 6

Dari tabel diatas untuk kecanggihan teknologi informasi $\left(\mathrm{X}_{1}\right)$ memiliki nilai $\mathrm{t}_{\text {hitung }}$ sebesar 2,217. Nilai ini lebih besar dari $t_{\text {tabel }}$ 2,048 dan signifikansi sebesar 0,035 lebih kecil dari 0,05. Sehingga dapat disimpulkan bahwa variabel kecanggihan teknologi informasi berpengaruh positif terhadap kinerja sistem informasi akuntansi. Untuk partisipasi pengguna $\left(\mathrm{X}_{2}\right)$ memiliki nilai $t_{\text {hitung }}$ sebesar 1,333. Nilai ini lebih kecil dari tabel 2,048 dan signifikansi sebesar 0,193 lebih besar dari 0,05. Sehingga dapat disimpulkan bahwa variabel partisipasi penggunaa tidak berpengaruh terhadap kinerja sistem informasi akuntansi. Untuk kemampuan pengguna $\left(\mathrm{X}_{3}\right)$ memiliki nilai $t_{\text {hitung }}$ sebesar 3,183. Nilai ini lebih besar dari $t_{\text {tabel }} 2,048$ dan signifikansi sebesar 0,004 lebih kecil dari 0,05. Sehingga dapat disimpulkan bahwa variabel kemampuan pengguna berpengaruh positif terhadap kinerja sistem informasi akuntansi.

Uji Koefisien Determinasi R²

Adjusted $\mathrm{R}^{2}$ pada intinya digunakan untuk mengukur seberapa jauh kemampuan model dalam menerangkan variasi variabel dependen.

Tabel 7. Hasil Uji Koefisien Determinasi

\begin{tabular}{llll}
\hline $\mathrm{R}$ & R.Square & Adjusted R Square & Std. Error of the Estimate \\
\hline $0,638^{\mathrm{a}}$ & 0,466 & 0,409 & 2,51070 \\
\hline
\end{tabular}

Dari tabel diatas dapat dilihat bahwa besarnya adjusted $\mathrm{R}^{2}$ adalah 0,638 atau sebanyak $63,8 \%$ variasi variabel kinerja sistem informasi akuntansi dapat dijelaskan oleh ketiga variabel independen yaitu kecanggihan teknologi informasi akuntansi, partisipasi pengguna, dan kemampuan pengguna. Sedangkan sisanya $(100 \%-63,8 \%=36,2 \%)$ dijelaskan oleh sebab-sebab yang lain diluar variabel yang telah ditentukan.

\section{Simpulan dan saran}

Berdasarkan hasil penelitian dan pembahasan bab 4, maka dapat ditarik kesimpulan sebagai berikut. a) Hasil pengujian hipotestis telah membuktikan bahwa kecanggihan teknologi informasi berpengaruh positif dan signifikan terhadap kinerja sistem informasi akuntansi. Hal ini membuktikan bahwa semakin tinggi kecanggihan teknologi informasi yang dipakai maka kinerja sistem informasi pada PT. PLN (Persero) area Jember juga akan semakin baik. b) Hasil pengujian hipotesis telah membuktikan bahwa partisipasi pengguna tidak berpengaruh terhadap kinerja sistem informasi akuntansi. Hal ini membuktikan bahwa semakin rendah partisipasi pengguna dalam perusahaan maka kinerja sistem informasi akuntansi pada PT. PLN (Persero) area Jember juga semakin buruk. c) Hasil pengujian hipotesis telah membuktikan bahwa partisipasi pengguna berpengaruh positif dan signifikan terhadap kinerja sistem informasi akuntansi. Hal ini membuktikan bahwa semakin tinggi kemampuan pengguna dalam 
suatu perusahaan maka kinerja sistem informasi akuntansi pada PT. PLN (Persero) juga akan semakin baik dan bagus.

\section{Daftar Rujukan}

Acep Komara. 2005. Analisis Faktor-faktor Yang Mempengaruhi Kinerja Sistem Informasi Akuntansi., SNAVIII. Solo.

Azhar Susanto. 2013. Sistem Informasi Akuntansi. Bandung: Lingga Jaya.

Baridwan. Zaki. 2000. Sistem Informasi Akuntansi. Edisi Ketiga. Penerbit BPFE. Yogyakarta

Bodnar, George H. dan William Hopwood S. 2000. Sistem Informasi Akuntansi. Jakarta: Salemba Empat.

Bodnar, G. H. Dan W. S. Hopwood. (Amir Abadi Jusuf dan Rudi M. Tambunan, Penerjemah). 2006. Sistem Informasi Akuntansi. Edisi Keenam. Jakarta: Salemba Empat

Edison, H. J., Levine. R., Ricci, L., \& Slok, T. 2002. International financial integration and economic growth. National Bureau of Economic Research Working Paper Series, No.9164.

Evi Saviana. 2017. Pengaruh Kecanggihan Teknologi Informasi, Partisipasi Manajemen, dan Pengetahuan Manajer Akuntansi pada Evektivitas Sistem Informasi Akuntansi. Skripsi S1 Akuntansi. Universitas Muhammadiyah Yogyakarta.

Ni Putu Alannita, I Gusti Ngurah Agung Suaryana. 2014. Pengaruh Kecanggihan Teknologi Informasi, Partisipasi Manajemen, dan Kemampuan Teknik Pemakai Sistem Informasi Akuntansi pada Kinerja Individu. E-Jurnal Akuntansi. Universitas Udayana.

Nugerahamawati, Astuti. 2013. Pengaruh Partisipasi Pemakai Sistem Informasi, Kemampuan Pemakai Sistem Informasi, Ukuran Organisasi Terhadap Kinerja Sistem Informasi Akuntansi dengan Kompleksitas Tugas sebagai Variabel Moderating (Studi pada PT. PLN (Persero) Distribusi Jawa Barat dan Banten). Universitas Pasunda. Bandung. Download http//www.google.com. 